\title{
Medium firm mattresses reduced pain related disability more than firm mattresses in chronic, non-specific low back pain
}

Kovacs FM, Abraira V, Peña A, et al. Effect of firmness of mattress on chronic non-specific low-back pain: randomised, double-blind, controlled, multicentre trial. Lancet 2003;362:1599-604.

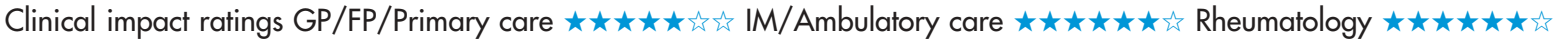

What is the effect of different firmnesses of mattresses on the clinical course of chronic, non-specific, low back pain and disability?

\section{METHODS}

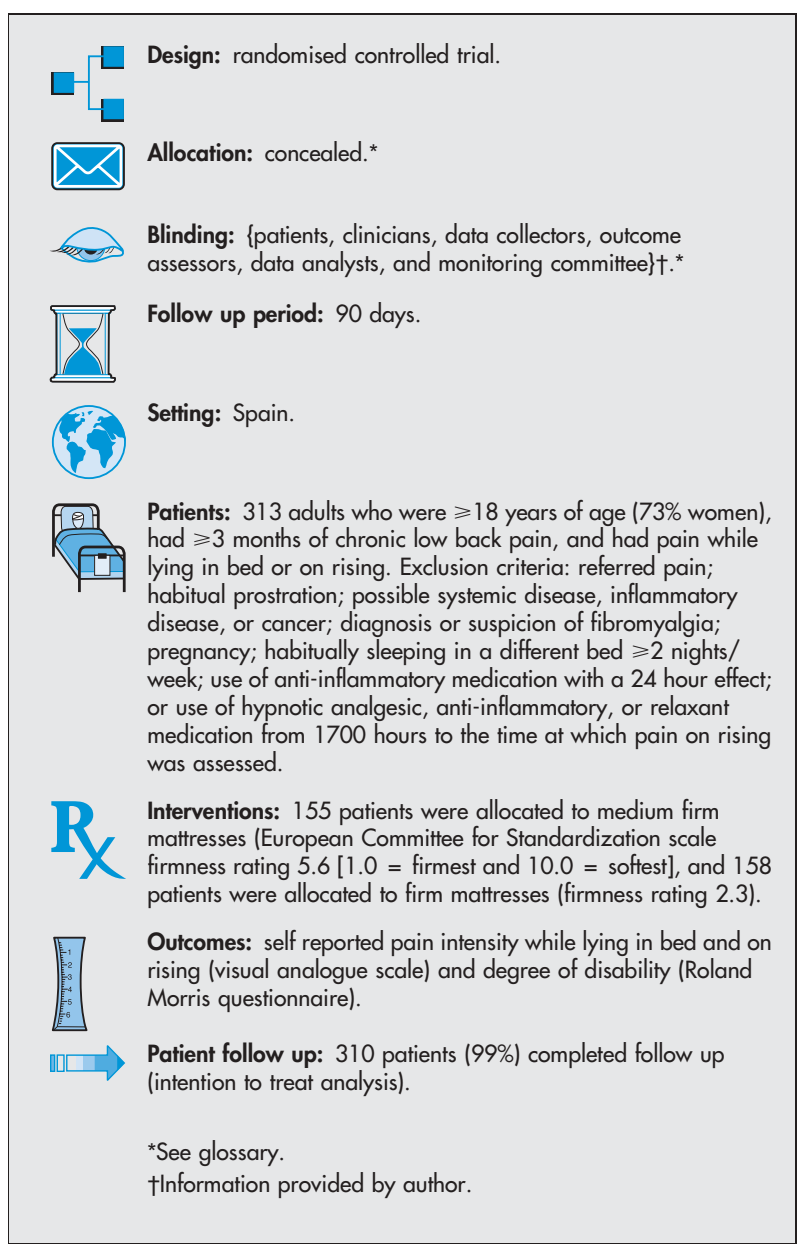

\section{MAIN RESULTS}

Patients who used medium firm mattresses were more likely to have improvements in pain related disability than were patients who used firm mattresses (table). The groups did not differ for improvement in pain while lying in bed or improvement in pain on rising (table).

\section{CONCLUSION}

In patients with chronic, non-specific low back pain, medium firm mattresses reduced pain related disability more than firm mattresses, but did not affect pain while lying in bed or on rising.

Abstract and commentary also appear in ACP Journal Club.

For correspondence: DrF $\mathrm{M}$ Kovacs, Kovacs Foundation, Palma de Mallorca, Spain. kovacs@kovacs.org

Sources of funding: Kovacs Foundation. Mattresses were provided by FLEX.
Medium firm mattress $v$ firm mattress for chronic, nonspecific low back pain*

\begin{tabular}{|c|c|c|c|c|}
\hline $\begin{array}{l}\text { Outcomes at } 90 \\
\text { days }\end{array}$ & $\begin{array}{l}\text { Medium } \\
\text { firm } \\
\text { mattress }\end{array}$ & $\begin{array}{l}\text { Firm } \\
\text { mattress }\end{array}$ & $\begin{array}{l}\text { RBI } \\
(95 \% \mathrm{CI})\end{array}$ & NNT (Cl) \\
\hline $\begin{array}{l}\text { Improvement in } \\
\text { pain while lying } \\
\text { in bed }\end{array}$ & $83 \%$ & $78 \%$ & $\begin{array}{l}6.1 \% \\
(-6 \text { to } 15)\end{array}$ & $\begin{array}{l}\text { Not } \\
\text { significant }\end{array}$ \\
\hline $\begin{array}{l}\text { Improvement in } \\
\text { pain on rising }\end{array}$ & $86 \%$ & $80 \%$ & $\begin{array}{l}6.8 \% \\
(-4 \text { to } 20)\end{array}$ & $\begin{array}{l}\text { Not } \\
\text { significant }\end{array}$ \\
\hline $\begin{array}{l}\text { Improvement in } \\
\text { pain related } \\
\text { disability }\end{array}$ & $82 \%$ & $68 \%$ & $\begin{array}{l}20 \% \\
(7 \text { to } 30)\end{array}$ & $8(5$ to 23$)$ \\
\hline
\end{tabular}

*Abbreviations defined in glossary. RBI, NNT, and Cl calculated from control event rates and unadjusted odds ratios in article. Improvement $=$ a positive change in pain intensity between baseline and 90 days.

\section{Commentary}

$\mathrm{D}$ on't recommend a firm mattress for someone with chronic low back pain. And, despite the findings of Kovacs et al, don't recommend a medium firm mattress either. The ideal mattress, if such exists, is still unknown. Advice to sleep on a firm mattress to palliate persistent regional backache exits the ranks of the unproven and joins the ever growing ranks of the disproved. Hundreds of other methods have suffered this fate. Based on the evidence, little more than over the counter analgesics ${ }^{1}$ and advice to stay active ${ }^{2}$ should be offered.

The firmer mattress has now lost its competitive edge, thanks to the findings of the trial by Kovacs et al. The between group differences are persuasive but must be interpreted cautiously because most study patients correctly perceived the firmness of their new mattress, meaning that blinding was unsuccessful. More impressive is that $>70 \%$ of patients had improvement in back pain regardless of the type of new mattress they received. This trial of a treatment method was itself a treatment. The nonspecific (Hawthorne and placebo) effects dwarfed the small between group differences.

How is it that simply participating in the trial could be palliative? Clearly, participation overcame whatever thwarted recovery from many months of back pain. The context of the trial must have engendered a sufficient sense of wellness in patients such that they could downplay, ignore, or even forget their pain. The pain is in their backs, but the suffering is in their minds. There are less expensive means of coping than buying a new medium firm mattress. ${ }^{3}$

Nortin M Hadler, MD University of North Carolina at Chapel Hill and UNC Hospitals Chapel Hill, North Carolina, USA Arthur T Evans, MD, MPH Cook County Hospital and Rush Medical College Chicago, Illinois, USA

1 van Tulder MW, Scholten RJ, Koes BW, et al. Spine 2000;25:2501-13.

2 Hagen KB, Hilde G, Jamtvedt G, et al. Spine. 2002;27:1736-41.

3 Hadler NM. The last well person. Montreal: McGill-Queens University Press, 2004 